\title{
PENGEMBANGAN MODEL MANAJEMEN PELATIHAN DAN PENGEMBANGAN PENDIDIKAN KARAKTER BERLOKUS PADEPOKAN KARAKTER
}

\section{Maman Rachman ${ }^{\bowtie}$, Masrukhi, Aris Munandar, dan Andi Suhardiyanto}

Jurusan Politik dan Kewarganegaraan, Fakultas Ilmu Sosial, Universitas Negeri Semarang

\section{Info Artikel}

Sejarah Artikel:

Diterima 19 Okt 2017

Disetujui 31 Okt 2017

Dipublikasikan Des 2017

\section{Keywords:}

Management training,

character education,

padepokan karakter

\begin{abstract}
This research develops a model of characteristic training and character education management to produce academic, profession, and vocational (potential teacher and teacher) teachers who have superior competence in disseminating noble character of the nation. By using Researh \& Development approach, this research uses Padepokan Character locus PPKn FIS Unnes Department. The subjects of the study were the newly graduated Unnes students, the young teachers in Semarang City and Central Java Province. The factual model of training management and the development of character education that runs so far contains weaknesses in various aspects, from planning, implementation, to evaluation of activities. On the basis of the analysis of a number of weaknesses of the factual model is then carried out the reconstruction of the conceptual model departs from the review of ethical factors and emotic factors. Conceptual model is then refined again by accommodating the results of focus group discussion with the stake holders and utilize the potential and resources owned by the character padepokan Unnes Political Education and Citizenship. This model has incorporated various aspects of the training, from the refinement of the factual model greed, the consideration of ethical factors and the emotional factors, as well as the aspirations and needs of the stake holders, so it is feasible to experiment in the wider domain.
\end{abstract}

\begin{abstract}
Abstrak
Penelitian ini mengembangkan model manajemen pelatihan dan pendidikan karakter berlokus padepokan karakter guna menghasilkan tenaga akademik, profesi, dan vokasi (calon guru dan guru) yang memiliki kompetensi unggul dalam menyebarluaskan karakter luhur bangsa. Dengan menggunakan pendekatan Researh \& Development, penelitian ini menggunakan lokus Padepokan Karakter Jurusan PPKn FIS Unnes. Subjek penelitian adalah para mahasiswa Unnes yang baru lulus, para guru muda di Kota Semarang dan Provinsi Jawa Tengah. Model factual manajemen pelatihan dan pengembangan pendidikan karakter yang berjalan selama ini mengandung kelemahan pada berbagai aspek, mulai dari perencanaan, pelaksanaan, sampai evaluasi kegiatan. Atas dasar analisis terhadap sejumlah kelemahan model factual tersebut kemudian dilakukan rekonstruksi model konseptual berangkat dari penelaahan faktor-faktor etik dan faktor emik. Model konseptual tersebut kemudian disempurnakan lagi dengan mengakomodasikan hasil focus group discussion dengan para stake holders dan mendayagunakan potensi dan sumber daya yang dimiliki oleh padepokan karakter Jurusan Pendidikan Politik dan Kewarganegaraan Unnes. Model ini telah memadukan berbagai aspek pelatihan, mulai dari penyempurnaan dari kelamahan model factual, pertimbangan faktor etik dan faktor emik, serta aspirasi dan kebutuhan para stake holders, sehingga layak untuk dilakukan uji coba dalam ranah yang lebih luas.
\end{abstract}

(C) 2017 Universitas Muria Kudus
p-ISSN 2087-9385

e-ISSN 2528-696X

Program Studi Pendidikan Guru Sekolah Dasar
Fakultas Keguruan dan Ilmu Pendidikan Universitas Muria Kudus
Kampus UMK Gondangmanis, Bae Kudus Gd. L. 1t I PO. BOX 53

Kudus

Tlp (0291) 438229 ex.147 Fax. (0291) 437198

E-mail: maman.rachman@mail.unnes.ac.id;

masrukhi@mail.unnes.ac.id 


\section{PENDAHULUAN}

Pembangunan bangsa dan pembangunan karakter merupakan persoalan mendasar bagi keberlangsungan sebuah bangsa. Bagi bangsa Indonesia pembangunan karakter ini memiliki panduan yang sudah jelas yaitu berdasarkan Pancasila sebagai pandangan hidup bangsa dan dasar negara. Ideologi Pancasila merupakan keseluruhan pandangan, cita-cita, maupun keyakinan dan nilai-nilai bangsa Indonesia secara normatif perlu diwujudkan dalam tata kehidupan berbangsa dan bernegara guna mewujudkan tercapainya suatu keadilan sosial bagi seluruh rakyat Indonesia.

Dalam dinamika perjalanannya, pendidikan karakter bangsa ini mengalami masamasa suram, terutama ketika bangsa Indonesia memasuki awal-awal era reformasi. Euforia sebagai dampak pengiringnya menjadikan tatanan pendidikan karakter bangsa kehilangan arah. Pada satu sisi nilai-nilai lama dalam kehidupan berbangsa dan bernegara ingin ditinggalkan, pada sisi lain nilai-nilai baru yang bersumber dari reformasi masih dirasakan belum ada wujudnya. Pancasila sebagai ideologi nasional dan acuan nation and character building meredup. Karakter Pancasila kehilangan roh sejatinya apalagi ditunjang oleh arus teknologi dan informasi terbuka vulgar tanpa batas dan tak terkendali. Hal itu semua pasti mengganggu terciptanya pertahanan negara NKRI

Upaya bangsa dan negara Indonesia untuk mencapai tujuan nasional, khususnya dalam dunia pendidikan telah banyak dilakukan, sejak awal kemerdekaan sampai sekarang. Upayaupaya yang dilakukan dalam pembentukan karakter, akhir-akhir ini sebagai berikut.

Pertama, Pemerintah Republik Indonesia telah mengeluarkan Kebijakan Nasional Pembangunan karakter Bangsa Tahun 2010-2025 (Pemerintah RI, 2013). Kebijakan Nasional Pembangunan Karakter Bangsa ini disusun sebagai pelaksanaan amanat Rencana Pembangunan Jangka Panjang Nasional Tahun 2005-2025. Kebijakan Nasional Pembangunan Karakter Bangsa ini juga dimaksudkan sebagai panduan dalam merancang, mengembangkan, dan melaksanakan Rencana Aksi Nasional Pembangunan Karakter Bangsa dengan mendorong partisipasi aktif dari berbagai komponen bangsa.

Kedua, Departemen Pendidikan dan Kebudayaan telah menyusun Naskah Akademik Pendidikan Karakter di Perguruan Tinggi (Dirjen Dikti, 2013). Pada Bab III dari Naskah Akademik Pendidikan Karakter di Perguruan Tinggi dikemukakan bahwa nilai-nilai dasar karakter Dikti (jujur, cerdas, tangguh, dan peduli) perlu dibangun korelasinya dengan budaya akademik, mimbar akademik, dan hakekat pendidikan. Selanjutnya dikemukakan bahwa nilai-nilai dasar, budaya akademik, mimbar akademik, dan harkat pendidikan diarahkan agar Dikti mampu mewujudkan dirinya sebagai pusat keilmuan dan kebudayaan, dan juga juga agar Dikti mampu memandu perubahan yang terjadi dalam masyarakat untuk menyelesaikan persoalan bangsa. Implmentasi pendidikan karakter dalam perspektif budaya akademik, pendidikan karakter tidak ditempatkan berdiri sendiri, namun ditempatkan asimilatif. Artinya pendidikan karakter ini digabungkan dengan pendidikan akademik, kemudian memberikan pemahaman baru. Selanjutnya, strategi implementasi pendidikan karakter di lingkungan perguruan tinggi dapat dibagi atas tiga sektor, yaitu kelembagaan, kegiatan kurikuler, dan kegiatan non-kurikuler.

Adapun program nyata untuk penguatan pendidikan karakter di Perguruan tinggi, antara lain: (1) menyusun desain induk pendidikan karakter, (2) hibah penulisan buku best practices pendidikan karakter, (3) rintisan pusat pengembangan pendidikan karakter, (4) hibah program pendidikan karakter, (5) pelatihan dosen Mata Kuliah Pembinaan Kepribadian (MPK) dan Mata Kuliah Berkehidupan Berbangsa (MBB), (6) pengiriman dosen PKn Perguruan Tinggi ke luar negeri dalam rangka penyegaran Civic Education, (7) deklarasi anti nyontek dan anti plagiat, (8) Deklarasi Penguatan Pilar-pilar Kebangsaan, Semiloka Penguatan Wawasan Kebangsaan bagi Dosen dan Mahasiswa (Dirjen Dikti, 2014).

Dengan tidak menafikan keberhasilan yang diraih, belakangan ini terjadi maraknya kekerasan di kalangan pelajar dan mahasiswa, mulai dari nyontek, tidak mengerjakan pekerjaan rumah, tawuran, perkelahian, korban sodomi, penganiayaan, pengeroyokan, kekerasan seksual, ketagihan narkoba, sampai pembunuhan, dan sebagainya (Hadisaputro, 2004; Borba, 2008; Shintanindya, 2011; Aditya, 2015). Kejadiankejadian kekerasan seperti itu, menunjukkan penyimpangan moral dan karakter pada generasi muda, khususnya. Isyarat lain menunjukkan bahwa perlunya upaya yang lebih keras, berkelanjutan dan berkesinambungan dilakukan oleh semua pihak dalam penguatan karakter.

Pada dunia pendidikan formal, dosen/guru memegang peran penting dalam keikutsertaan menanggulangi perilaku menyimpang pada mahasiswa/siswa. LPTK dipandang perlu memberi tambahan kompetensi menyemai nilainilai karakter. Oleh karena itu, pelatihan para 
calon guru dan para guru diasumsikan dapat memberi kontribusi preventif menyemai nilainilai karakter dalam kerangka mengurangi perilaku menyimpang para mahasiswa/siswa di persekolahan dan perguruan tinggi khususnya. Padepokan karakter FIS Unnes adalah sebuah wadah yang dapat digunakan sebagai tempat memberi tambahan strategi penguatan karakter dan penguasaan kompetensi nilai-nilai karakter bagi para calon guru dan para guru.

Kajian ini memiliki makna strategis. Secara teoretis-strategis, kajian penelitian ini akan menambah khasanah ilmu pengetahuan, terutama mengembangkan teori yang terkait dengan model pelatihan dan pengembangan pendidikan karakter. Di samping itu, pelatihan pendidikan berwawasan karakter bersifat sistemik organik, dengan ciri-ciri fleksibeladaptif dan kreatif-demokratis. Bersifat sistemikorganik berarti lokus pelatihan dan pengembangan pendidikan karakter merupakan tempat, proses yang bersifat interaktif dari keseluruhan interaksi yang ada. FleksibelAdaptif, berarti pelatihan dan pengembangan pendidikan karakter lebih ditekankan sebagai suatu proses pembelajaran dari pada mengajar. Peserta pelatihan (calon guru dan guru) dirangsang memiliki motivasi untuk mempelajari sesuatu yang harus diperbaharui dan diterapkan dalam pembelajaran yang berkelanjutan. Materi pelatihan dan pengembangan bersifat terpadu, kontekstual, dan berkelanjutan.Kreatifdemokratis, berarti pelatihan senantiasa menekankan pada suatu sikap mental untuk senantiasa menghadirkan sesuatu yang baru dan orisinil. Secara pedagogis dan andragogis, kreativitas dan demokrasi merupakan dua sisi dari mata uang. Tanpa demokrasi tidak akan ada proses kreatif, sebaliknya tanpa proses kreatif demokrasi tidak akan memiliki makna.

Selain itu, menambah model pelatihan dan pengembangan komprehensif dan berkelanjutan terkait dengan pendidikan karakter. Berbagai macam metode pelatihan yang dilakukan para instruktur, pada dasarnya dimaksudkan untuk memenuhi kebutuhan kompetensi keterampilan peserta yang diharapkan mengimbas pada pembelajaran dosen/guru-siswa/mahasiswa di kelas. Keterlibatan para peserta secara non fisik atau dalam pemikiran dan hati, hal inilah yang harus menjadi perhatian para peserta. Sebab, banyak para peserta yang tidak memperhatikan hal ini dan menyalahkan siswa/mahasiswa di kelas, ketika mereka tidak kreatif dalam merespon materi yang diberikan. Untuk mencegah adanya pemikiran yang menyalahkan siswa/mahasiswa, peserta pelatihan dan pengembangan sebagai seorang pendidik harus kreatif dalam mengembangkan pembelajaran, terutama yang berbasis dan bersifat kontekstual. Sebab, dengan mengkaitkan dengan masalah-masalah kontekstual akan mampu meningkatkan keterlibatan peserta. Selanjutnya, jika pemikiran dan hati telah menyatu dalam mengikuti pelatihan dan pengembangan, maka pemahaman komprehensif telah terjadi. Kedua hal tersebut, pelatihan pendidikan global dan pendidikan komprehensif akan dapat diperoleh dan ditemukenali pada wadah yang disebut pedepokan karakter, seperi dirancang dalam penelitian ini.

Sedangkan secara praktis-operasional, penelitian ini meneguhkan konsekuensi dan komitmen semua pihak dalam melaksanakan pendidikan karakter, khususnya Unnes mulai dari hilir sampai ke hulu, mulai dari para calon guru dan para guru di sekolah. Caranya antara lain ialah dengan memberi kondisi kearah terciptanya peningkatan kompetensi profesional, personal, sosial, dan pedagogi para calon guru dan para guru. Sehubungan dengan hal tersebut, untuk merealisasikan pendidikan karakter perlu dilakukan secara utuh melalui berbagai program, metode, dan pendekatan. Selain itu, kurikulum di perguruan tinggi dan sekolah harus dikembangkan secara progresif dalam rangka membantu generasi muda untuk dapat mencapai kehidupan yang secara pribadi lebih memuaskan dan secara sosial lebih konstruktif (Zuchdi, 2001). Oleh karena itu, tersedianya para guru muda yang baru lulus dan para guru yang terlatih berbasis pelatihan dan pengembangan karakter pada Padepokan Karakter FIS Unnes akan mengimbas kepada keterampilan mengelola kelas dengan mengintegrasikan karakter secara utuh, komperhensif, dan berkesinambungan.

\section{METODOLOGI}

Penelitian ini menggunakan pendekatan penelitian dan pengembangan (Researh \& Development) yang dimodifikasi dari Borg and Gall (1983), yang kemudian disederhanakan menjadi tiga langkah inti dari sepuluh langkah. Ketiga langkah tersebut yaitu studi pendahuluan, pengembangan model, dan validasi model pelatihan dan pengembangan pendidikan karakter. Mengacu kepada kelemahan pelatihan pendidikan karakter saat ini, pelatihan dan pengembangan pendidikan karakter dapat dioptimalkan dengan menggunakan lokus padepokan karakter pada Padepokan Karakter FIS Unnes.

Lokus atau lokasi penelitian ini dilakukan di Padepokan Karakter FIS Unnes dengan subjek penelitian para calon guru mahasiswa lulusan 
Unnes yang akan diwisuda (Tahun ke-1), para guru muda Kota Semarang (Tahun ke-2), dan para guru Provnsi Jawa Tengah (tahun ke-3).

Untuk memperoleh produk model dan perangkat yang efektif akan dilakukan uji validasi dan uji coba kepada: (1) para ahli dan praktisi, (2) uji coba kelompok, dan (3) uji coba lapangan terbatas.

Alat penjaring data: wawancara, dokumentasi, observasi, dan angket. Instrumen pengumpul data: pedoman wawancara, catatan lapangan, lembar observasi, dan anket terbuka.

Dalam melakukan analisis data, dilakukan langkah-langkah berikut. Pertama, menganalisis kebutuhan, tujuan, materi, persiapan pelaksanaan, dan evaluasi pelatihan dan pengembangan pendidikan karakter dilakukan melalui analisis interaktif dengan langkah pengumpulan data, reduksi data, display data, dan simpulan. Kedua, menganalisis keefektifan model pelatihan dan pengembangan dilakukan dengan menggunakan "one-group pretest posttest design".

\section{HASIL DAN PEMBAHASAN}

Pelatihan dan pengembangan pendidikan karakter merupakan upaya yang harus dilakukan secara kontinyu dan sistematis, agar diperoleh hasil yang maksimal. Hal ini dikandung maksud agar proses pendidikan karakter dapat dilaksanakan dengan efektif, baik di lingkungan kampus maupun di sekolah. Upaya pemerintah saat ini dalam melatih dan mengembangkan pendidikan karakter sudah berjalan dengan baik, mulai dari tataran regulasi, kebijakan, maupun praksisnya di lapangan. Beberapa aksi yang dilakukan oleh kemeenterian diantaranya adalah menyusun desain induk pendidikan karakter, hibah penulisan buku best practices pendidikan karakter, rintisan pusat pengembangan pendidikan karakter, hibah program pendidikan karakter, pelatihan dosen Mata Kuliah Pembinaan Kepribadian (MPK) dan Mata Kuliah Berkehidupan Berbangsa (MBB), pengiriman dosen PKn Perguruan Tinggi ke luar negeri dalam rangka penyegaran Civic Education, deklarasi anti nyontek dan anti plagiat, deklarasi Penguatan Pilar-pilar Kebangsaan, Semiloka Penguatan Wawasan Kebangsaan bagi Dosen dan Mahasiswa, dan sebagainya.

Terlepas dari berbagai hasil yang capai, sampai saat ini di kalangan pelajar dan mahasiswa masih kerapkali terjadi tindakantindakan kekerasan. Beberapa fenomena yang sering dijumpai adalah perbuatan nyontek, tidak mengerjakan pekerjaan rumah, tawuran, perkelahian, korban sodomi, penganiayaan, pengeroyokan, kekerasan seksual, ketagihan narkoba, sampai pembunuhan, dan sebagainya. Melihat realita demikian, menunjukan perlunya penyempurnaan model pelatihan dan pengembangan pendidikan karakter.

Studi terhadap pelaksanaan pelatihan dan pengembangan pendidikan karakterselama ini ditunjukkan masih adanya kekurangan di sana sini, yang memerlukan penyempurnaan secara komprehensif. Hal ini sangat terasakan sejak analisis kebutuhan dan kegunaan pelatihan yang dirasakan kurangnya perencanaan secara komprehensif. Demikian juga dalam hal materi, peserta, dan instruktur secara berjenjang dan berkelanjutan juga masih dirasakan lemah.Selain hal tersebut di atas perencanaan dalam hal tata kelola juga belum terorganisasikan dengan baik. Belum ada keterpaduan berbagai komponen, sehingga terkesan berjalan sendiri-sendiri.

Evaluasi kegiatan pendidikan karakter belum dilakukan secara komprehensif.Sesuai dengan hakekat pendidikan karakter, pengukuran keberhasilan pembelajarannya tidak hanya berkenaan dengan aspek kognitif saja, melainkan keterpaduan antara aspek kognitif, afektif, dan psikhomotorik. Oleh karena itu evaluasi kegiatan haruslah merupakan kegiatan yang evaluasi yang komprehensif.

Dalam hal pengelolaan waktu pendidikan pelatihan dan pengembangan pendidikan karakter, juga belum terjadi pengelolaan yang efektif. Artinya waktu yang ada dapat dimanfaatkan secra maksimal untuk penyelenggaraan pelatihan dan pengembangan pendidikan karakter dengan target out come yang maksimal. Salah satu penyebab belum efektifnya pengelolaan pelatihan dan pengembangan pendidikan karakter adalah faktor sumber pengayaan dalam proses pembelajaran yang masih sangat terbatas.

Dalam hal pelaksanaannya selama ini, dirasakan bahwa materi yang disajikan belum terfokus pada esensi pendidikan karakter serta penyajiannya pun dirasakan belum komprehensif. Materi masih disajikan secara parsial dan lebih banyak menyajikan aspek kognisinya, atau pengetahuan tentang pendidikan karakter. Hal ini menjadikan proses pendidikan karakter yang ada selama ini belum mencapai sasaran substansialnya. Selain itu, kontekstualisasi materi juga belum terjadi. Artinya materi yang disajikan dalam pelatihan belum dikaitkan dengan fakta atau pengalaman nyata sehari-hari.Agar lebih mudah dicerna oleh para peserta, mestinya sajian materi dikaitkan dengan kehidupan sehari-hari para peserta.

Terkait dengan materi sajian yang kurang komprehensif, yang hanya berkenaan dengan aspek kognitif, demikian juga dengan 
pelaksanaan evalasinya. Instrument evaluasi yang ada kurang konsisten dengan karakteristikpendidikan karakter, karena lebih banyak berkenaan dengan aspek pengetahuan saja. Itulah sebabnya pelaksanaan pendidikan karakter selama ini kurang memperoleh hasil yang maksimal.

Hal lain yang tidak kalah penting terkait dengan pelaksanaan pendidikan karakter ini adalah suasana di luar kelas. Di era digital sekarang ini, instruktur dan buku pelatihan bukan satu-satunya sumber belajar. Para peserta akan dengan mudah mengakses informasi dari luar kelas melalui media baik cetak maupun elektronik, yang kerapkali isinya kontra produktif dengan pendidikan karakter yang diajarkan di kelas. Selain itu beberapa tradisi di masyarakat pun masih kuran mendukung terhadap pelaksanaan pendidikan karakter, ditambah lagi dengan fenomena bahwa instruktur pendidikan karakter kerapkali pula belum menjiwai dirinya untuk menjadi teladan bagi para peserta didik dengan baik.

Secara visual dapat digambarkan model factual pelaksanaan pelatidan dan pengembangan pendidikan karakter seperti terlihat pada gambar 4.1 seperti berikut.

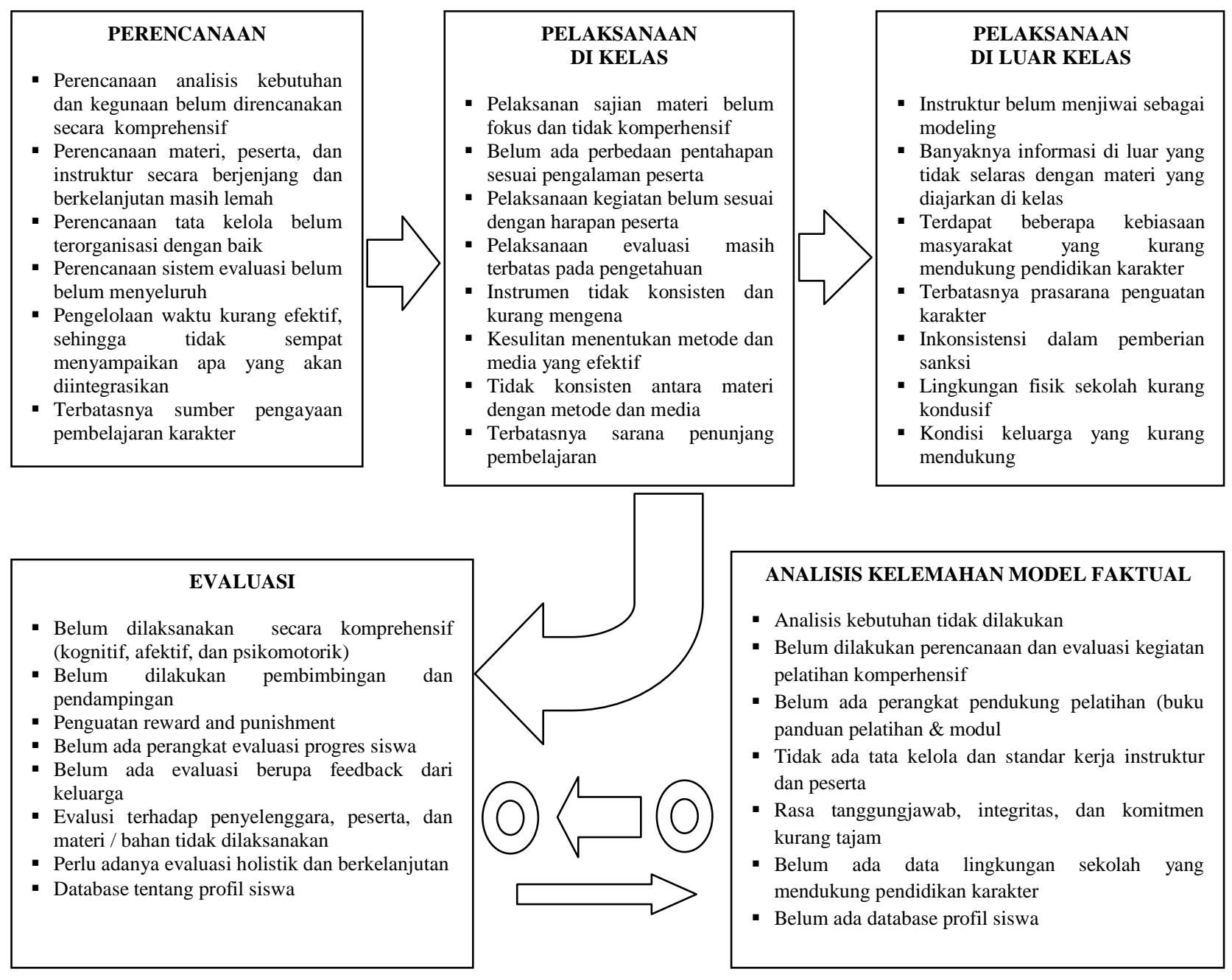

(Gambar 4.1 model factual Manajemen Pelatihan dan Pengembangan Pendidikan Karakter) 
Pada model factual seperti tervisualisasikan pada gambar 4.1 di atas, tampak beberapa kelemahan yang cukup substansial; mulai dari perencanaan, pelaksanaan baik di dalam kelas maupun di luar kelas, sampai evaluasi pelaksanaan.

Atas dasar kelemahan-kelemahan yang ada pada model factual mengenai manajemen pelatihan dan pengembangan pendidikan karakter,dengan mempertimbangkan pula potensi-potensi yang dimiliki oleh padepokan karakter Jurusan Pendidikan Politik dan Kewarganegaraan Unnes, maka dilakukan pemodelan pelatihan yang lebih sempurna dengan mendayagunakan potensi lokus padepokan karakter.

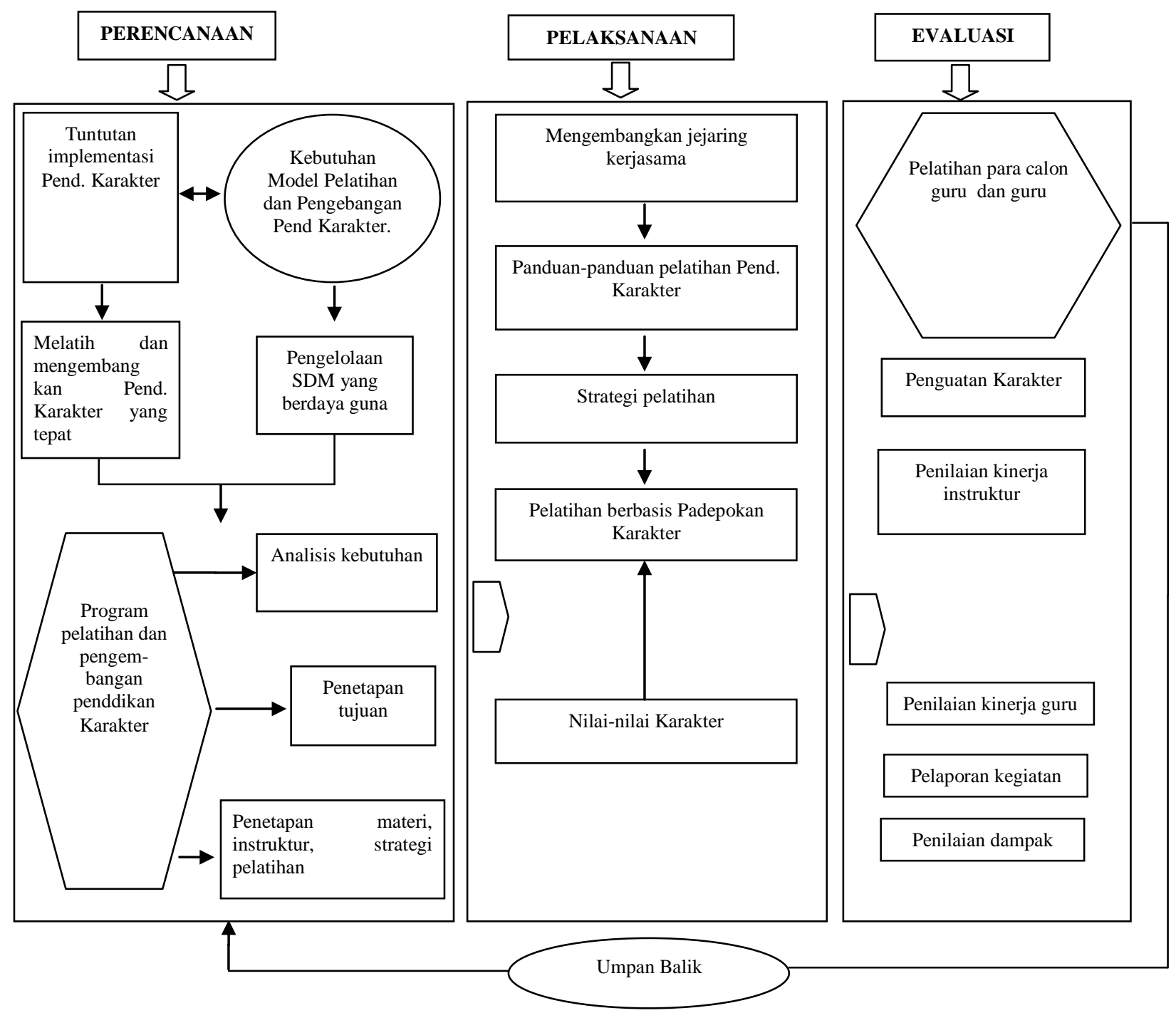

(Gambar 4.2 Model Hipotetik Manajemen Pelatihan dan Pengembangan Pendidikan Karakter Berlokus Padepokan Karakter
Hasil penyempurnaan model pelatihan ini pun masih merupakan model hipotetik yang kelak harus dilakukan uji coba keterterapannya di lapangan. Hasil penyempurnaan model Manajemen Pelatihan dan Pengembangan Pendidikan Karakter yang berlokus padepokan karakter ini, terlihat pada gambar 4.2 berikut di bawah ini. 
Pada model hipotetik seperti terlihat pada gambar 4.2 di atas tampak adanya upaya untuk melakukan rekonstruksi pemodelan pelatihan dan pengembangan pendidikan karakter, yang kontekstual dengan berloku spada padepokan karakter. Padepokan karakter di Jurusan Pendidikan Politik dan Kewaganegaraan sangat potensial untuk pengembangan model pelatihan pendidikan karakter, oleh karena keberadaanya dikandung maksud sebagai pusat informasi, pendidikan, penyajian dan promosi berbagai hal yang menyangkut tujuan padepokan, pusat berbagai kegiatan yang berhubungan dengan upaya pelestarian, pengembangan, penyebaran dan peningkatan citra dan nilai-nilai yang yang dikembangkan pada padepokan terkait. Selain itu padepokan ini juga dimaksudkan sebagai sarana untuk memperkokoh persatuan dan kesatuan masyarakat sesuai tujuan padepokan terkait, sarana mempererat persahabatan di antara masyarakat padepokan sesuai visi dam misi padepokan, serta sarana memasyarakatkan kode etik dan ikrar padepokan terkait.

Kelemahan-kelamahan substansial yang ada pada model factual disempurnakan sedemikan rupa, sejak perencanaan, pelaksanaan, sampai pada evaluasi kegiatan. Dengan demikian pada model hipotetik ini, sudah dilakukan perpaduan antara penyempurnaan model pengembangan berangkat dari kelemahankelamahan model factual dengan pemberdayaan segala potens yang ada pada padepokan karakter, sehingga model yang tercipta adalah manajemen pelatihan dan pengembangan pendidikan karakter yang terencana secara sistematis, kontekstual, dengan memberdayakan potensi yang ada pada padepokan karakter.

Model hipotetik yang tercipta ini kemudian dimajukan kepada para guru serta lulusan jurusan PPKn tahun 2016 untuk memperoleh masukan penyempurnaan kembali, melalui focus group discussion.

Hasil focus group discussion terhadap model hipotetik tersebut menunjukkan keberterimaan dari para peserta terhadap model model pelatihan dan pengembangan pendidikan karakter berlokus padepokan karakter.Semua peserta FGD memberikan apresiasinya yang sangat positif dengan harapan untuk dapat secepatnya diterapkan di lapangan.

Beberapa catatan penting dari hasil FGD guna penyempurnaan model hipoteti. Pertama, materi yang dilatihkan terkadang kurang jelas sehingga pelatihan kerapkali dirasakan hanya untuk mengejar keterlaksanaannya saja, tanpa bisa mengetahui hasil pelatihannya. Kedua, aspek spiritual seperti yang selama ini menjadi tuntutan di dalam Kurikulum 2013, kurang memperoleh porsi yang maksimal. Hal ini menjadikan pelatihan pendidikan karakter yang selama ini diikuti para guru kurang bisa memberikan jawaban terhadap guru di lapangan. Ketiga, kontekstualisasi materi pelatihan juga dirasakan sangat kurang, karena pada umumnya materi yang disajikan sangat normative dan kurang berkenaan dengan kehidupan sehari-hari. Keempat, masih dirasakan kurangnya buku-buku dan referensi untuk mengembangkan pendidikan karakter, termasuk juga pada saat pelatihan pendidikan karakter.

Hasil FGD dengan para guru tersebut kemudian dielaborasi ke dalam model hipotetik yang ada, sehingga terbangunlah model akhir manajemen pelatihan dan pengembangan pendidikan karakter berlokus padepokan karakter, seperti terpolakan pada gambar 4.3 berikut ini. 


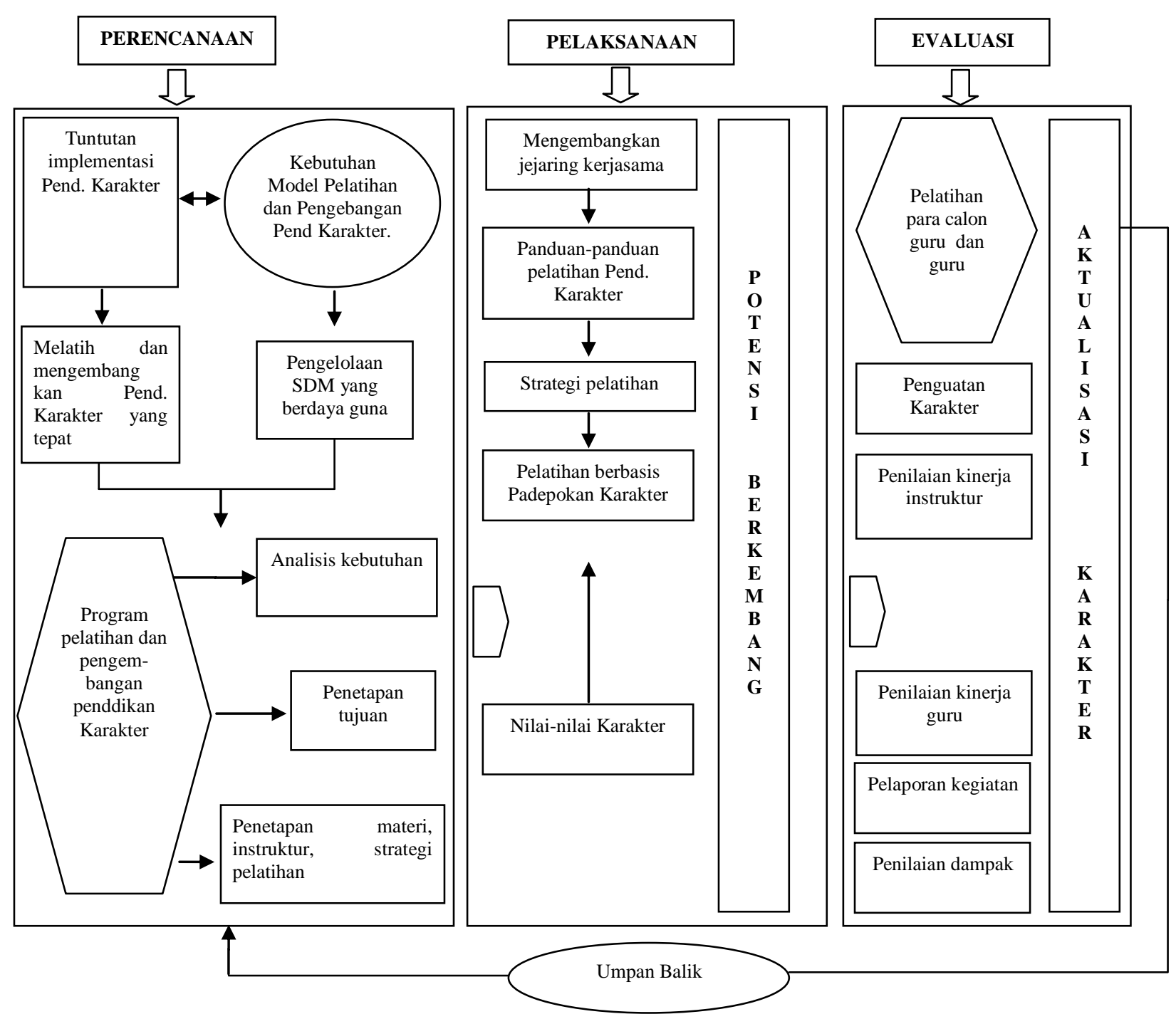

Gambar 4.3 Model Akhir Manajemen Pelatihan dan Pengembangan Pendidikan Karakter Berlokus Padepokan Karakter. 
Model akhir seperti yang disajikan pada gambar 4.3 tersebut merupakan manajemen pelatihan dan pengembangan pendidikan karakter berlokus padepokan karakter, yang telah memadukan model factual, yang setelah dianalisis akan kelemahan-kelamahannya kemudian dilakukan rekonstruksi, dengan hasil focus group discussion, dengan para guru SD SMP SMA di kota Semarang.

Sejak perencanaan kegiatan, model manajemen ini telah memulainya dengan analisis kebutuhan, dilanjutkan dengan penetapan tujuan akan manajemen pelatihan dan pengembangan pendidikan karakter, penetapan instruktur, materi, dan strategi pelatihan. Semua aspek terkait dengan pelaksanaan kegiatan pelatihan telah dirancang secara sistematis. Selanjutnya dalam tahap palaksanaan kegiatan pelatihan telah disiapkan buku panduan pelatihan, buku materi pelatihan, dan media pelatihan yang tepat sehingga memudahkan peserta pelatihan untuk menyerap materi kegiatan pelatihan. Dalam hal penyusunan buku panduan kegiatan pelaksanaan, buku materi pelatihan, serta media pelatihan, didasarkan atas potensi dan sumber daya yang dimiliki oleh padepokan karakter Jurusan PPKn FIS Unnes.

Selanjutnya untuk keperluan evaluasi, model ini pun menawarkan seperangkat instrument penilaian, mulai dari perangkat penilaian instruktur, instrument kinerja guru, instrument pelaporan, sampai pada instrumen penilaian dampak kegiatan. Perangkat instrumen ini mengacu kepada substansi pendidikan karakter secara komprehensif, baik kognitif, afektif, maupun psikhomotor.

Model akhir manajemen pelatihan dan pengembangan pendidikan karakter berlokus padepokan karakter ini memiliki kebaruan berupa akomodasi berbagai anasir dalam pendekatan pendidikan karakter, yang disusun secara sistematis sejak perencanaan, pelaksanaan sampai evaluasi kegiatan pelatihan. Lima pendekatan pendidikan karakter/nilai terakomodir dalam model tersebut, adalah pendekatan penanaman nilai (inculcation approach), pendekatan perkembangan moral kognitif (cognitive moral development approach), pendekatan analisis nilai (values analysis approach), pendekatan klarifikasi nilai (values clarification approach), dan pendekatan pembelajaran berbuat (action learning approach) (Superka, et. al. 1976, Zakaria, 2000; Rachman, 2001, 2002).

Dari lima pendekatan pendidikan nilai tersebut, peran guru menjadi sangat strategis oleh karena berhubungan langsung dengan proses pembelajaran di dalam kelas. Kendatipun berbagai sumber belajar di era digital ini mudah diperoleh melalui internet, akan tetapi dalam konteks pendidikan karakter peran guru tidak dapat tergantikan oleh sumber daya apa pun. Oleh karena itu guru profesional yang memiliki kompetensi unggul dalam menyebarluaskan karakter luhur bangsa sangat penting keberadaannya di tengah-tengah peserta didik. Di tangan guru professional inilah akan terjadi proses pembelajaran dan pembinaan karakter melalui upaya kreatif dan inovatif dalam mengembangkan model-model pembelajaran agar dapat terjadi internalisasi nilai-nilai karakter lebih efektif.

\section{PENUTUP}

Pengembangan pendidikan karakter di lembaga pendidikan harus terus diupayakan untuk lebih berkualitas. Pelatihan dan pengembangan pendidikan karakter kepada para guru menjadi sangat penting artinya, sebagai upaya secara sistematis bagi pembinaan karakter oleh para guru di sekolah masing-masing.

Padepokan karakter di Jurusan Pendidikan Politik dan Kewaganegaraan sangat potensial untuk pengembangan model pelatihan pendidikan karakter, oleh karena keberadaanya dikandung maksud sebagai pusat informasi, pendidikan, penyajian dan promosi berbagai hal yang menyangkut tujuan padepokan, pusat berbagai kegiatan yang berhubungan dengan upaya pelestarian, pengembangan, penyebaran dan peningkatan citra dan nilai-nilai yang yang dikembangkan pada padepokan terkait. Selain itu padepokan ini juga dimaksudkan sebagai sarana untuk memperkokoh persatuan dan kesatuan masyarakat sesuai tujuan padepokan terkait, sarana mempererat persahabatan di antara masyarakat padepokan sesuai visi dam misi padepokan, serta sarana memasyarakatkan kode etik dan ikrar padepokan terkait.

Keunggulan dari model akhir manajemen pelatihan dan pengembangan pendidikan karakter berlokus padepokan karakter ini adalah adanya dimilikinya kebaruan berupa diintegrasikannya berbagai anasir dalam pendekatan pendidikan karakter, yang disusun secara sistematis secjak perencanaan, pelaksanaan sampai evaluasi kegiatan pelatihan.

\section{DAFTAR PUSTAKA}

Aditya, Kreshna. 2015. Kekerasan Anak Pelajar. Tersedia pada www.bincangedukasi.com

Asmawi, J.M. 2011. Buku Panduan Internalisasi Pendidikan Karakter di Sekolah. Jogyakarta: DIVA Press. 
Banks, J.A. 1985. Teaching Strategies for the Social Studies. New York: Longmen.

Borba, M. 2008. Membangun Kecerdasan Moral: Tujuh Kebijakan Utama agar Anak Bermoral Tinggi. Gramedia Pustaka Utama. Jakarta.

Borg, W.R. and Gall, M.D. 1983. Educational Research: An Introduction. London: Longman, Inc.

Budiningsih, Asri. 2004. Pembelajaran Moral Berpijak pada Karakteristik Siswa dan Budayanya. Jakarta: PT Rineka Cipta.

Bungin, Burhan. 2010. Analisis Data Penelitian: Pemahaman Filosofis dan Metodologis ke Arah Penguasaan Model Aplikasi. Jakarta: Rajawali Press.

Garcia, T. 2005. Organization and Management. Pholiines: Stanfilco.

Craig. 1976. Training and Development Handbook: A Guid Resource Development. New York: Longman Inc.

Hadisaputro, P. 2004. Studi Tentang Makna Penyimpangan Perilaku Di Kalangan Remaja. Jurnal Kriminologi Indonesia 3 (3), hlm: 9-18.

Hasan, S. Hamid. 2012. Pendidikan Sejarah untuk Memperkuat Pendidikan Karakter. Paramita Jurnal Sejarah dan Pembelajaran Sejarah.

Kusdiyah, Rachmawati. 2008. Manajemen Sumber Daya Manusia. Yogyakarta: Andi.

Kusuma, Doni A. 2007. Pendidikan Karakter, Strategi Mendidik Anak di Zaman Global. Jakarta: Grasindi.

Latif, Yudi. 2009. Menyemai Karakter Bangsa, Budaya Kebangkitan Berbasis Kesastraan. Jakarta: Penerbit Kompas.

LP2M Unnes. 2016. Rencana Strategis 20152019. Semarang: LP2M Unnes.

LPPKB. 2007. Membangun karakter bangsa dengan jalan Memperkokoh Jati diri Bangsa. Jakarta: LPPKB.
Mondy, R.W. 2008. Manajemen Sumber Daya Manusia, Edisi Kesepuluh (terjemahan). Jakarta: Penerbit Erlangga.

Mulyasa, Enco. Manajemen Pendidikan Karakter. Jakarta: Bumi Aksara.

PnPSI.2011. Padepokan Pencak Silat Indonesia. Jakarta: PnSPI.

Puskur. 2010. Pedoman Pengembangan Pendidikan Budaya dan Karakter Bangsa bagi Sekolah. Jakarta: Kementerian Pendidikan Nasional

Rachman, Maman. 2009. Model Pemberdayaan Masyarakat Menuju Perilaku Tanggap Diri pada Daerah Rawan Bencana Banjir. Penelitian Srategis Nasional. Semarang: Universitas Negeri semarang.

Rachman, Maman. 2010. Filsafat Ilmu dan Manajemen Pendidikan. Semarang: PPS Unnes.

Rachman, Maman. 2001. Reposisi, Reevaluasi dan Redefinisi Pendidikan Nilai bagi Generasi Muda Bangsa. Jurnal Pendidikan dan Kebudayaan 7 (028), hlm: 1-11.

Rachman, Maman. 2002. Implementasi Pendidikan Budi Pekerti dalam Keterpaduan Pembelajaran. Jurnal Pendidikan dan Kebudayaan 8 (036), hlm: 376-387..

Raths, L.E., Harmin, M. \& Simon, S.B. 1978. Values and Teaching: Working with Values in the Classroom. Second Edition. Columbus: Charles E. Merrill Publishing Company.

Rest, J.R. 1992 Komponen-komponen Utama Moralitas. Dlm. Kurtines, W.M.\& Gerwitz, J.L. (pnyt.). Moralitas, perilaku moral, dan perkembangan moral: 37-60. Terj. Soelaeman, M.I. \& Dahlan, M.D. Jakarta: PenerbitUniversitas Indonesia.

Superka, D.P. 1973. A typology of valuing theories and values education approaches. Doctor of Education Dissertation. University of California, Berkeley.

Superka, D.P., Ahrens, C., Hedstrom, J.E., Ford, L.J. \& Johnson, P.L. 1976. Values education sourcebook. 
Rachman, M., Masrukhi., Munandar, A., Suhardiyanto, A./ Jurnal Refleksi Edukatika 8 (1) (2017)

Colorado: Social Science Education Consortium, Inc.

Suryana, Yoyon. 2008. Pengembangan Sumber Daya Manusia. Yogyakarta: Gama Media.

Sastroatmodjo, Sudijono. 2010. Wisuda Universitas Negeri Semarang. Semarang: Unnes Pres

Zakaria, Teuku Ramli. 2000. Pendekatanpendekatan Pendidikan Nilai dan Implementasi. Jurnal Pendidikan dan Kebudayaan 6 (026).

Zuchdi.Darmiyati. 2001. "Pendekatan Pendidikan Nilai Secara Komprehensif Sebagai Suatu Alternatif Pembentukan Akhlak Bangsa". Makalah Seminar. Yogyakarta: Lembaga Penelitian UNY, 11 Juni 2001.

Zuchdi, D. dkk. 2010. Pendidikan Karakter dengan Pendekatan Komprehensif: Terintegrasi dalam Pengembangan Kultur Universitas. Yogyakarta: UNY Press. 